\title{
PENGARUH PERSEPSI SISWA PADA MATA PELAJARAN BIOLOGI DAN EKSPEKTASI KARIR TERHADAP REGULASI DIRI DAN HASIL BELAJAR BIOLOGI
}

\author{
Oleh \\ Ni Putu Oka Milarika ${ }^{1}$, I Made Candiasa², Ni ketut Widiartini ${ }^{3}$. \\ Program Studi Penelitian dan Evaluasi Pendidikan, Program Pascasarjana \\ Universitas Pendidikan Ganesha \\ Singaraja, Indonesia
e-mail: \{mila_rika@yahoo.com¹,candiasa@pasca.undiksha.ac.id², ketut.widiartini@pasca.undiksha.ac.id $\left.{ }^{3}\right\}$

\begin{abstract}
Abstrak
Penelitian ini bertujuan untuk mengetahui pengaruh persepsi siswa pada mata pelajaran biologi, ekspektasi karir, dan regulasi diri terhadap hasil belajar biologi. Penelitian ini adalah penelitian ex-post facto dengan pendekatan jalur. Variabel eksogenus dalam penelitian ini adalah persepsi siswa pada mata pelajaran biologi dan ekspektasi karir, sedangkan variabel endogenusnya adalah regulasi diri dan hasil belajar biologi. Penelitian ini dilakukan di SMA Laboratorium Undiksha Singaraja pada siswa kelas X MIA dengan besar sampel 43 orang siswa. Data persepsi siswa pada mata pelajaran biologi, ekspektasi karir, dan regulasi diri dikumpulkan dengan angket, sedangkan data hasil belajar diperoleh dari nilai ulangan harian dan penilaian akhir semester. Data dianalisis dengan analisis jalur (pathway analysis). Hasil penelitian menunjukkan bahwa: 1) ada pengaruh yang signifikan persepsi siswa pada mata pelajaran biologi terhadap regulasi diri, 2) ada pengaruh yang signifikan ekspektasi karir terhadap regulasi diri 3) ada pengaruh langsung persepsi siswa pada mata pelajaran biologi terhadap hasil belajar biologi 4) ada pengaruh langsung ekspektasi karir terhadap hasil belajar biologi 5) ada pengaruh tidak langsung persepsi siswa terhadap hasil belajar biologi melalui regulasi diri, dan 6) ada pengaruh tidak langsung ekspektasi karir terhadap hasil belajar biologi melalui regulasi diri. Dengan demikian dapat disimpulkan bahwa peningkatan hasil belajar biologi dapat diupayakan dengan peningkatan persepsi siswa, ekspektasi karir, dan regulasi diri.
\end{abstract}

Kata kunci: ekspektasi karir, hasil belajar biologi, regulasi diri, persepsi

Abstract
This study aims to determine the effect of students' perceptions on biology subjects, career expectations and self-regulation towards biology learning outcomes. This research was an ex-post facto with pathway approach. Exogenous variables in this study were students' perceptions on biology subjects and career expectations, while endogenous variables were self-regulation and biology learning outcomes. This research was conducted at SMA Laboratorium Undiksha Singaraja in X Grade Natural Science students with total sample were 43 students. The data in this study were collected using student perception questionnaires on biology subjects, career expectations, and self-regulation. While learning outcomes data was collected from tests and final test. Data was analyzed by pathway analysis. The result show 1) there are effects of students 'perception on biology subject toward self-regulation, 2) there are effects of career expectation toward self-regulation, 3) there are direct effects of students' perception on biology subject toward biology learning outcomes, 4) there are direct effects of career expectations toward biology learning outcomes, 5) there are indirect effects of students' perception on biology subject toward biology learning outcomes through self-regulation, and 6) there are indirect effects of career expectations toward biology learning outcomes through self-regulation. So it can be 
conclude that the improvement of biology learning outcomes can be pursue from increase of student perception, carrer expectation, and self-regulation.

Keywords : career expectations, learning outcomes, self-regulation, studens' perception

\section{PENDAHULUAN}

Siswa belajar melalui sebuah proses pembelajaran untuk mendapatkan sejumlah kompetensi pada berbagai mata pelajaran yang telah dikelompokkan sesuai dengan jurusan yang dipilih. Untuk mengetahui sejauh mana siswa belajar dilakukanlah proses penilaian yang akan menghasilkan hasil belajar. Hasil belajar ini sering kali bermasalah, dimana sebagian besar hasil belajar siswa jauh dari ketuntasan belajar minimal yang ditetapkan. Beberapa penelitian yang dilakukan terkait dengan hasil belajar lebih banyak membahas tentang pengaruh dari IQ, motivasi belajar, serta model pembelajaran terhadap hasil belajar. Tidak banyak yang membahas tentang bagaimana persepsi siswa pada suatu mata pelajaran mempengaruhi hasil belajar. Padahal salah satu faktor internal yang mempengaruhi hasil belajar adalah persepsi siswa terhadap mata pelajaran.

Mata pelajaran Biologi merupakan salah satu mata pelajaran yang ada pada peminatan IPA. Pendapat dari siswa yang menyatakan bahwa biologi merupakan pelajaran yang paling mudah diantara mata pelajaran peminatan IPA. Hasil penelitian terkait persepsi siswa pada mata pelajaran IPA (science) juga diungkapkan oleh Prokop, dkk (2007) dimana mata pelajaran IPA membosankan bagi banyak siswa, susah, tidak relevan bagi kehidupan manusia dan kurang menarik bagi siswa pada kelas yang lebih tinggi. Meskipun pendapat tersebut tidak bisa digeneralisasikan kepada semua mata pelajaran IPA. Ada perbedaan cara pandang siswa antara mata pelajaran fisika dan biologi. Pandangan siswa terhadap fisika lebih negatif dari pada biologi. Namun siswa laki-laki lebih tertarik pada fisika sedangkan siswa wanita lebih tertarik pada biologi.

Pengamatan awal yang dilakukan pada siswa kelas $X$ tentang pemilihan mata pelajaran peminatan IPA di Ujian Nasional, sebanyak $80 \%$ siswa memilih mata pelajaran biologi. Masalah yang ditemui dalam pelaksanaan pembelajaran biologi adalah rendahnya nilai rata-rata kelas yang diperoleh oleh siswa saat penilaian baik kuis, ulangan harian maupun penilaian akhir semester. Fakta di sekolah tentang rendahnya rata-rata pada pelajaran biologi yang merupakan mata pelajaran peminatan IPA yang nantinya akan dipilih di Ujian Nasional.

Menurut penelitian yang dilakukan oleh Nugraini (2015) menyatakan bahwa banyak siswa kesulitan belajar biologi, dan mereka berpikir bahwa biologi hanya mengutamakan hafalan. Beberapa materi sangat susah dimengerti oleh siswa diantaranya yaitu pembelahan sel dan metabolisme. Penyebab dari sulitnya siswa belajar biologi adalah gaya guru mengajar, gaya siswa belajar, persepsi negatif siswa terhadap pelajaran, dan kurangnya sumber belajar. Siswa merasa sulit belajar biologi dan kehilangan minat belajar karena siswa merasa apa yang dipelajari kurang relevan bagi kehidupan sehari-hari.

Menurut Sarwono (2010) persepsi merupakan proses kategorisasi. Organisme dirangsang oleh suatu masukan tertentu (objek-obejek atau peristiwa) dan organisme itu berespon dengan menghubungkan masukan itu dengan salah satu kategori (golongan) objek-objek atau peristiwa. Proses menghubungkan ini adalah proses yang aktif dimana individu bersangkutan dangan sengaja mencari kategori yang tepat sehingga ia dapat mengenali atau memberi arti masukan tersebut.

Pemilihan jurusan pada siswa kelas $\mathrm{X}$ tidak dapat dipisahkan dari ekspektasi karir masa depan mereka. Pendidikan pada akhirnya berujung pada dunia kerja. Ada banyak pilihan karir yang dapat dipilih oleh siswa nantinya terkait mata pelajaran biologi seperti pada bidang kesehatan, pertanian, kehutanan, kelautan, industri yang memanfaatkan organisme hidup dan pendidikan. Namun 
saat dilakukan observasi awal, sebagian besar siswa menyatakan tidak memikirkan cita-cita mereka saat memilih jurusan di kelas $X$. Siswa kelas $X$ belum mampu menyatakan keinginan mereka untuk mendalami bidang mata pelajaran tertentu. Mereka menyatakan ketertarikan pada bidang-bidang biologi namun tidak memiliki rencana ke depan untuk menjadikannya suatu pilihan karir.

Manrihu (1988) mendefinisikan karier sebagai sekuensi okupasi-okupasi dimana seseorang ikut serta di dalamnya, beberapa orang mungkin tetap dalam okupasi yang sama sepanjang hidupnya, sedangkan yang lainnya mungkin memiliki rangkaian okupasi-okupasi yang berbeda.

Dalam memperoleh pilihan karir yang tepat seseorang harus dapat melakukan perencanaan yang tepat, yang erat kaitannya dengan regulasi diri (selfregulation) dan informasi yang diperoleh. Maka dari itu perencanaan karir yang tepat berasal dari pengaturan diri dan lingkungan yang tepat pula (Istriyanti dan Nocholas, 2014).

Kemampuan

seseorang

mengontrol pikiran, tindakan atau perilakunya di dalam pencapaian tujuan belajarnya, menurut Zimmerman (2008) disebut sebagai regulasi diri.

Keberhasilan seseorang dalam menjalankan proses pendidikannya tidak hanya ditentukan oleh tingkat intelegensi (IQ) yang dimilikinya, tetapi dibutuhkan juga kemampuan meregulasi dirinya selama mengikuti proses pendidikan. Kemampuan ini lebih dikenal dengan istilah regulasi diri (self-regulation) meliputi kemampuan untuk mulai mencoba menentukan nilai yang ingin diperolehnya, merencanakan membuat jadwal pelajaran, membagi waktu antara belajar dan bermain, dan mempersiapkan diri dalam menghadapi ulangan sehingga pada akhirnya dapat meningkatkan prestasinya di sekolah (Susanto, 2006).

Hasil penelitian oleh Hargis yang dikutip dari Rozali (2014) menyatakan bahwa yang memiliki regulasi diri yang tinggi cenderung belajar lebih baik, mampu memantau, mengevaluasi, dan mengatur belajarnya secara efektif; menghemat waktu dalam menyelesaikan tugasnya (disebut engagement); mengatur belajar dan waktu secara efisien dan memperoleh skor yang tinggi dalam sains, yang dipengaruhi oleh faktor internal dan eksternal dari individu tersebut.

Hipotesis dari penelitian ini adalah untuk menguji adanya pengaruh persepsi siswa pada mata pelajaran biologi dan ekspektasi karir terhadap regulasi diri, pengaruh persepsi siswa pada mata pelajaran biologi secara langsung maupun tidak langsung terhadap hasil belajar melalui regulasi diri, serta adanya pengaruh ekspektasi karir secara langsung maupun tidak langsung terhadap hasil belajar melalui regulasi diri.

\section{METODE}

Penelitian ini termasuk dalam kategori penelitian ex-post facto. penelitian ini merupakan penelitian penelusuran kembali terhadap suatu peristiwa atau suatu kejadian dan kemudian merunut ke belakang untuk mengetahui faktor-faktor yang dapat menimbulkan kejadian tersebut. penelitian ini berusaha untuk mencari determinasi variabel persepsi siswa pada mata pelajaran biologi $\left(X_{1}\right)$ dan ekspektasi karir $\left(\mathrm{X}_{2}\right)$ terhadap regulasi diri $\left(\mathrm{X}_{3}\right)$ dan hasil belajar $(\mathrm{Y})$.

Dalam penelitian ini sampel yang digunakan adalah sampel jenuh yaitu seluruh populasi dengan pertimbangan jumlah populasi yang tidak terlalu besar. Besar sampel adalah 43 orang siswa kelas $X$ yang memilih peminatan IPA. Variabel eksogenus dalam penelitian ini adalah persepsi siswa pada mata pelajaran biologi $\left(\mathrm{X}_{1}\right)$ dan ekspektasi karir $\left(X_{2}\right)$. Variabel endogenus dalam penelitian ini adalah regulasi diri $\left(X_{3}\right)$, dan hasil belajar biologi $(\mathrm{Y})$. Data persepsi siswa pada mata pelajaran biologi, ekspektasi karir, dan regulasi diri dikumpulkan dengan angket, sedangkan data hasil belajar diperoleh dari nilai ulangan harian dan penilaian akhir semester.

Analisis data yang dilakukan adalah: (1) melakukan uji prasyarat yaitu uji normalitas, uji linearitas dan keberartian arah regresi, uji multikolinearita, uji autokorelasi, dan uji heteroskedastisitas. 
(2) uji model dengan menggunakan analisis jalur yang terbagi menjadi uji sub struktur 1 dan sub struktur 2 untuk menjawab hipotesis yang telah dirumuskan.

\section{HASIL DAN PEMBAHASAN}

Keempat data yang diperoleh berupa persepsi siswa pada mata pelajaran biologi, ekspektasi karir, regulasi dan hasil belajar akan dikategorisasi menjadi 3 yaitu tinggi, sedang dan rendah. Berdasarkan pengukuran ini dapat disusun sebaran frekuensi data hasil penelitian terlidat pada Gambar 1.1 berikut.

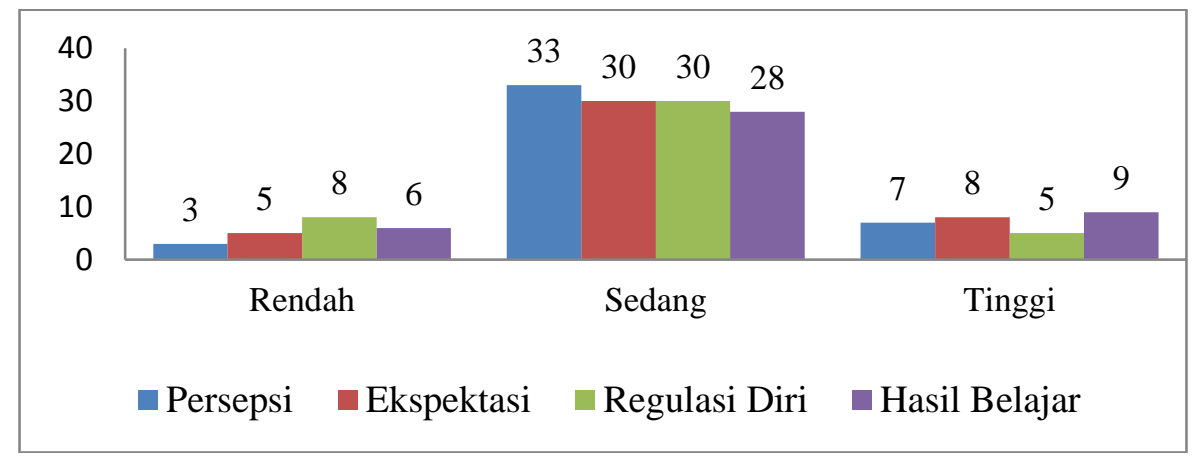

Gambar 1.1 Kategorisasi Hasil Penelitian

Data persepsi siswa pada mata pelajaran biologi, ekspektasi karir, regulasi diri dan hasil belajar yang telah diperoleh akan dianalisis secara kuantitatif dengan analisis jalur (pathway analysis). Data penelitian ini telah memenuhi uji prasyarat yaitu uji normalitas, uji keberartian arah regresi, uji linearitas, uji multikolinieritas, uji autokorelasi, dan uji heteroskedastisitas.
Setelah dilakukan uji pada sub struktur 1 dan sub struktur 2, kesemua koefisien jalur dinyatakan signifikan sehingga tidak perlu dilakukan trimming. Maka model yang diajukan di awal sama dengan model setelah dilakukan pengujian. Berikut ditampilkan diagram jalur penelitian beserta koefisien jalur dan besarnya pengaruh variabel lain secara lengkap pada Gambar 1.2.

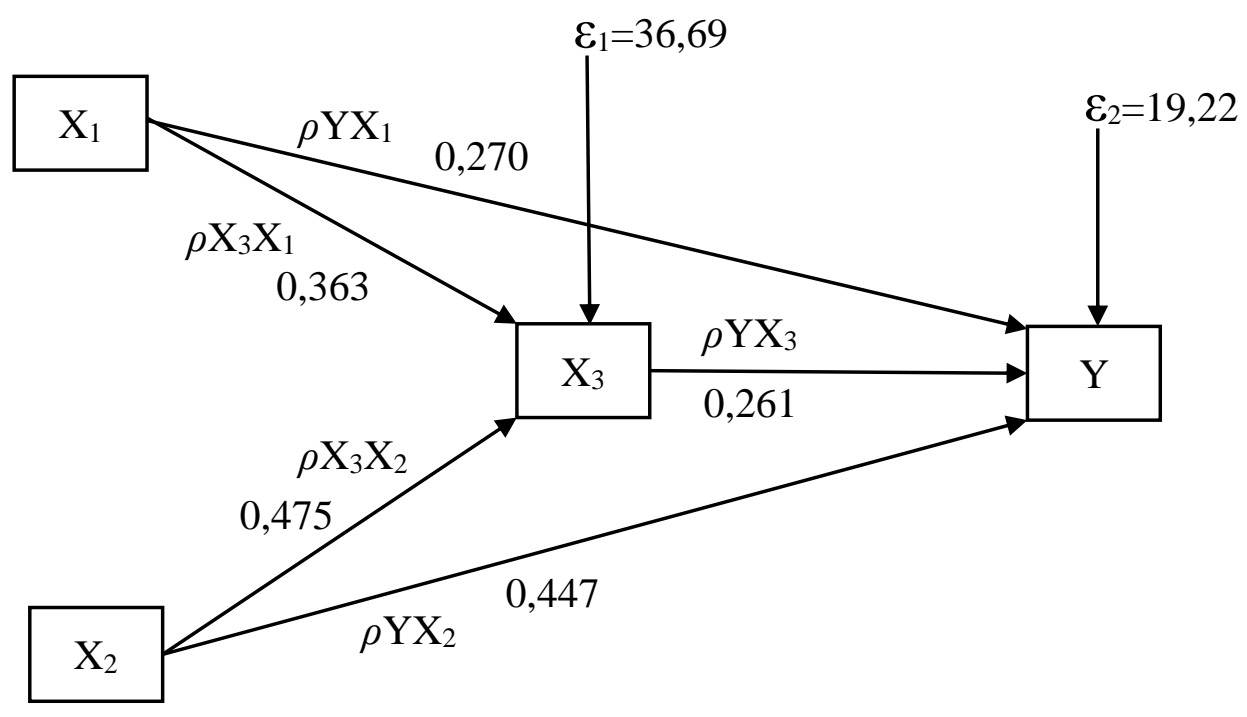




\section{Pengaruh Persepsi Siswa pada Mata Pelajaran Biologi Terhadap Regulasi Diri}

Berdasarkan uji hipotesis yang Dari hasil tabulasi data yang dilakukan berdasarkan rentang skor dari Selfregulation Questionnaire menunjukkan bahwa dari 43 orang siswa, 8 orang siswa memiliki regulasi diri tinggi, 30 orang siswa memiliki regulasi diri sedang dan 5 orang memiliki regulasi diri rendah. Dari hasil uji hipotesis yang dilakukan diketahui bahwa ada pengaruh persepsi siswa pada mata pelajaran biologi terhadap regulasi diri. Sebagian besar siswa memiliki persepsi sedang terhadap mata pelajaran biologi, begitu pula dengan regulasi diri. Sebagian besar siswa memiliki regulasi diri sedang.

Pengaruh positif persepsi terhadap regulasi diri diungkapkan dalam penelitian oleh Anggraeni (2015) menyatakan terdapat hubungan positif dan signifikan antara persepsi terhadap tugas akademik terhadap regulasi diri siswa. Semakin rendah persepsi terhadap tugas akademik semakin rendah juga regulasi diri siswa.

Dijelaskan lebih lanjut dalam penelitian oleh Anggraeni (2015) bahwa dengan persepsi, individu akan menyadari tentang keadaan di sekitarnya dan juga keadaan diri sendiri. Persepsi terhadap tugas akademik adalah penilaian dan penginterpretasian siswa terhadap tugas akademiknya. Intepretasi individual dicirikan sebagai konseptual pengharapan dan penghargaan. Sejauh mana harapan siswa akan sukses dalam menyelesaikan tugas akademiknya melahirkan tujuan yang akan dicapai. Adanya keinginan untuk mencapai tujuan tersebut maka akan muncul regulasi diri untuk mencapainya. Regulasi diri inilah yang berperan dalam mendekatkan atau menjauhkan siswa dari sasaran yang ingin dicapainya.

Hasil penelitian oleh Anggraeni sesuai dengan hasil penelitian ini di mana persepsi siswa pada mata pelajaran biologi berpengaruh terhadap hasil belajar. dengan persepsi pada mata pelajaran yang baik, maka akan muncul harapan untuk bisa. Harapan ini yang akan mempengaruhi regulasi diri siswa karena siswa akan mengubah tingkah lakunya yang kurang sesuai.

Siswa yang memiliki regulasi diri yang tinggi cenderung belajar lebih baik, mampu memantau, mengevaluasi, mengatur belajarnya secara efektif, menghemat waktu dalam menyelesaikan tugasnya, mengatur belajar dan waktu secara efisien, dan memperoleh skor yang tinggi dalam ilmu pengetahuan. Siswa yang mampu memiliki prestasi yang tinggi, adalah mereka yang mau terlibat aktif bertanya baik bertanya mengenai materi maupun yang berkaitan dengan tugas yang dimilikinya. Selain itu mereka juga dapat menyelesaikan dan menyerahkan tugas mandiri mereka sesuai dengan waktu yang ditentukan, cenderung memiliki hasil belajar atau prestasi yang maksimal (Rozali, 2014).

Siswa yang memiliki persepsi positif cenderung menyukai mata pelajaran biologi yang akan mengikuti proses belajar dengan baik. Dalam upaya mengikuti proses pembelajaran yang baik siswa akan memantau prilaku dirinya sendiri dan memodifikasi perilaku yang tidak sesuai untuk mencapai tujuan belajarnya.

Regulasi diri, yang merupakan suatu pengaturan dalam diri anak ketika berhadapan dengan rangsangan dari luar. Regulasi diri akan menjembatani pengaruh-pengaruh eksternal dengan kemampuan atau kapital yang dimiliki anak sebagai dasar untuk melakukan tindakan yang bertujuan, sehingga memungkinkan anak memiliki kontrol individual atas pikiran, perasaan, motivasi dan perilakunya. Dengan regulasi diri, anak akan mengetahui dan memahami perilaku seperti apa yang dapat diterima oleh lingkungannya. Pentingnya mengajarkan regulasi diri kepada anakanak untuk memberikan kesempatan yang lebih baik kepada mereka dalam rangka 
memanfaatkan potensi yang mereka miliki (Sadiyah, 2016).

\section{Pengaruh Ekspektasi Karir terhadap Regulasi Diri}

Dari hasil analisis data yang diperoleh, ditemukan bahwa ekspektasi karir memiliki pengaruh yang signifikan terhadap regulasi diri. Seperti yang diuraikan sebelumnya bahwa hasil tabulasi data yang dilakukan berdasarkan rentang skor dari Self-regulation Questionnaire menunjukkan bahwa dari 43 orang siswa, 8 orang siswa memiliki regulasi diri tinggi, 30 orang memiliki regulasi diri sedang dan 5 orang memiliki regulasi diri rendah. Dari 43 orang siswa, 5 orang memiliki ekspektasi karir yang rendah, 30 orang memiliki ekspektasi karir yang sedang, sedangkan 8 orang memiliki ekspektasi karir yang tinggi. Hasil uji hipotesis menunjukkan bahwa ada pengaruh ekspektasi karir terhadap regulasi diri. Jika ditelusuri pada data mentah penelitian ini terlihat bahwa siswa yang memiliki ekspektasi karir yang rendah juga memiliki regulasi diri yang rendah.

Suatu penelitian tentang kaitan karir dengan regulasi diri di Bali pernah dilakukan oleh Istriyati dan Nicholas tahun 2014, dimana hasil dari penelitian ini menunjukkan bahwa ada hubungan positif antara regulasi diri dan perencanaan karir pada remaja putri Bali. Nilai koefisien determinasi sebesar 0,354 yang berarti bahwa sumbangan yang diberikan oleh variabel regulasi diri terhadap perencanaan karir yaitu sebesar 35,4\%. Melalui regulasi diri seseorang dengan mudah akan menemukan gambaran masa depannya sehingga sangat penting untuk dapat mengembangkan keterampilan dalam melakukan regulasi diri.

Timbowo (2014) menyatakan pemilihan karir mengikuti pola yang runtut dan dipengaruhi oleh lingkungan sosiokultural individu. Dalam perjalanannya individu akan mampu mengidentifikasi, mengarah, dan mengakomodir orientasi minat, kapasitas, dan nilai kedalam proses tersebut. Berdasarkan teori yang dipaparkan oleh Timbowo terlihat bahwa dalam karir seseorang, regulasi diri berperan penting, di mana dengan regulasi diri yang baik tentu siswa akan mampu untuk mengidentifikasi mengarah, dan mengakomodir orientasi minat, kapasitas, dan nilai dalam suatu pilihan karir.

Siswa dengan ekspektasi karir tinggi akan memiliki dorongan untuk mengikuti proses pembelajaran dengan baik. Dorongan ini akan meningkatkan regulasi diri siswa dimana siswa akan mampu mengubah tindakan atau perilakunya untuk memodifikasi perilaku yang tidak sesuai di dalam pencapaian tujuan belajarnya.

\section{Pengaruh Langsung Persepsi Siswa pada Mata Pelajaran Biologi terhadap Hasil Belajar Biologi \\ Dari hasil tabulasi data yang} dilakukan, didapatkan hasil bahwa dari 43 orang siswa, 7 orang siswa memiliki persepsi tinggi, 33 orang siswa memiliki persepsi sedang, dan 3 orang memiliki persepsi rendah terhadap mata pelajaran biologi. Uji hipotesis dilakukan dengan analisis jalur untuk mengetahui pengaruh persepsi siswa pada mata pelajaran biologi terhadap hasil belajar, uji hipotesis memperoleh hasil bahwa ada pengaruh langsung persepsi siswa pada mata pelajaran biologi terhadap hasil belajar.

Penelitian yang dilakukan oleh Hussaini, dkk (2015) menegaskan bahwa sikap siswa terhadap pelajaran mempengaruhi hasil belajar. Saat sikap siswa positif maka hasil belajar mereka juga cenderung positif. Ada hubungan yang signifikan antara ketertarikan siswa terhadap hasil belajar. Oleh karena itu sangat penting mengetahui bagaimana sikap siswa terhadap mata pelajaran biologi.

Setiap orang memiliki cara pandang yang berbeda terhadap suatu objek. Jika seseorang suka atau tertarik pada suatu objek, biasanya dia juga akan tertarik untuk mengetahui segala hal yang menyangkut objek tersebut. Ataupun sebaliknya, jika seseorang sudah tidak tertarik bahkan berpandangan negatif 
terhadap suatu objek, biasanya dia tidak akan tertarik untuk mengetahui segala hal yang berkaitan dengan objek tersebut. Siswa yang memiliki persepsi positif cenderung menyukai mata pelajaran biologi yang akan berdampak pada hasil belajar, karena hasil belajar diperoleh dari suatu interaksi tindak belajar dan ditunjukkan dengan nilai tes yang diberikan guru. Pengungkapan hasil belajar sendiri meliputi segenap ranah penguasaan, pengetahuan atau keterampilan yang berubah sebagai akibat pengalaman dan proses belajar siswa. Siswa yang memiliki persepsi positif akan mengikuti proses belajar dengan baik sehingga akan menghasilkan hasil belajar yang baik pula. Saat ditelusuri siswa yang memiliki persepsi negatif memang siswa dengan nilai yang tergolong paling kecil diantara para siswa lainnya.

Menurut penelitian Kubiatko dkk (2017) yang mempelajari tentang berbagai faktor yang mempengaruhi persepsi siswa tentang matematika dan biologi menghasilkan beberapa temuan yaitu saat seorang guru mempresentasikan konten pelajaran, selama pelajaran tersebut bisa dimengerti dan dalam bentuk yang berarti serta kontennya dapat diterapkan ke situasi kehidupan nyata akan mendorong sikap siswa yang lebih positif terhadap biologi dan matematika. Hasil penelitian ini mengungkapkan bahwa kesukaran suatu mata pelajaran menentukan persepsi siswa. Siswa yang memahami pelajaran biologi cenderung memiliki persepsi yang positif. Hasil dari penelitian ini menegaskan bahwa jika para siswa diyakinkan tentang manfaat subjek untuk karir masa depan, mereka akan memiliki sikap positif terhadap subjek. Hasil dari penelitian tersebut menggambarkan hubungan positif yang signifikan antara sikap siswa terhadap subjek dan prestasi akademik mereka.

Kontribusi persepsi siswa pada mata pelajaran erat kaitannya dengan kebermanfaatan suatu mata pelajaran juga diungkap oleh penelitian Pujiastuti (2012) menyatakan bahwa persepsi siswa menyumbang kontribusi sebesar 39\% terhadap hasil belajar, di mana dijelaskan lebih lanjut bahwa persepsi siswa yang baik bergantung pada proses pembelajaran yang dilakukan guru IPA, di mana pembelajaran harus dibuat menjadi lebih bermakna.

\section{Pengaruh Langsung Ekspektasi Karir terhadap Hasil Belajar Biologi}

Dari hasil tabulasi data yang dilakukan menunjukkan bahwa dari 43 orang siswa, 5 orang memiliki ekspektasi karir rendah dan 30 orang memiliki ekspektasi karir sedang, dan 8 orang memiliki ekspektasi karir tinggi. Uji hipotesis dilakukan dengan analisis jalur untuk mengetahui pengaruh ekspektasi karir terhadap hasil belajar, uji hipotesis memperoleh hasil bahwa ada pengaruh langsung ekspektasi karir terhadap hasil belajar. Dengan sumbangan efektif yang sangat tinggi yang menunjukkan bahwa ekspektasi karir sangat berpengaruh terhadap hasil belajar siswa.

Beberapa hasil penelitian yang mendukung adanya pengaruh ekspektasi karir terhadap hasil belajar adalah dari Irmayanti dkk (2013) menghasilkan kesimpulan bahwa terdapat kontribusi yang positif dan signifikan ekspektasi karir terhadap prestasi belajar bahasa Inggris siswa sebesar 12,8\%. Serta hasil penelitian dari Timbowo (2014) menghasilkan data bahwa terdapat determinasi yang signifikan antara ekspektasi karir dengan prestasi belajar dengan sumbangan sebesar $18,40 \%$.

Penelitian lain yang mendukung bahwa karir merupakan sebagai salah satu aspek penentu hasil belajar dilakukan oleh Krisnawan (2013) yang mengungkapkan bahwa ekspektasi karir berkontribusi sebesar 18,3\% terhadap kualitas pelaksanaan pembelajaran praktikum. Memang dalam penelitian yang dilakukan oleh Krisnawan menyatakan bahwa ekspektasi hanya berkontribusi sebesar 18,3\% dikarenakan memang variabel yang digunakan adalah kualitas pelaksanaan pembelajaran praktikum.

Marliyah, dkk (2004) menyatakan bahwa pemilihan karir merupakan saat remaja mengarahkan diri kepada suatu tahap baru dalam kehidupan mereka, dengan memandang suatu posisi 
pekerjaan sebagai karir, maka remaja akan menentukan ke arah mana mereka akan menuju masa depan. Faktor internal yang mempengaruhi pemilihan karir adalah intelegensi, bakat dan minat, sifat kepribadian, keadaan fisik, nilai kehidupan, serta pengetahuan sedangkan faktor eksternal adalah status sosial ekonomi, pengaruh keluarga khususnya orang tua, pendidikan sekolah, pengaruh teman sebaya, serta latar belakang budaya. Ekspektasi merupakan sesuatu yang ada dalam diri individu yang terjadi karena adanya keinginan untuk mencapai hasil sesuai dengan tujuan. Berdasarkan teori karir dan ekspektasi tersebut dan hasil dari penelitian ini yang menunjukkan bahwa kontribusi ekspektasi karir terhadap hasil belajar sebesar 44,7\%, maka terlihat bahwa siswa yang memiliki ekspektasi karir yang tinggi akan menyukai situasi belajar yang bagus dalam artian kondusif dan kompetitif terutama pada mata pelajaran yang dapat menjadi dasar menuju karir yang diinginkan. Siswa dengan ekspektasi karir tinggi akan memiliki dorongan untuk mengikuti proses pembelajaran dengan baik dan akan terlihat pada hasil belajar yang baik. Karena hasil belajar diperoleh diperoleh dari suatu proses interaksi tindak belajar yang dilakukan siswa.

Ekspektasi karir berkontribusi cukup banyak pada hasil belajar, hasil belajar siswa pada sampel yang digunakan memang tergolong sedang, dangan hampir $76 \%$ siswa memiliki ekspektasi karir terkait biologi yang sedang pula. Sehingga hasil dari penelitian ini sesuai dengan teori-teori dan penelitian sebelumnya yang serupa, bahwa ekspektasi karir memiliki pengaruh yang signifikan terhadap hasil belajar.

\section{Pengaruh Tidak Langsung Persepsi Siswa terhadap Hasil Belajar Biologi Melalui Regulasi Diri}

Pada penelitian ini menunjukkan bahwa 43 orang siswa memiliki persepsi sedang pada mata pelajaran biologi dengan 28 orang siswa hasil belajarnya tergolong sedang. Setelah dibandingkan hasil dari rekapitulasi regulasi diri menunjukkan bahwa 30 orang siswa memiliki regulasi diri sedang. Sesuai dengan pembahasan sebelumnya bahwa persepsi memiliki pengaruh signifikan terhadap regulasi diri dan regulasi diri berpengaruh terhadap hasil belajar. Sesuai dengan pernyataan oleh Zimmerman (2008) bahwa regulasi diri merupakan kemampuan untuk mengontrol proses belajar. Anak yang memiliki regulasi diri, dalam kegiatan belajar terlihat aktif, memiliki ketekunan dan inisiatif dalam mengerjakan tugas-tugas, menguasai strategi-strategi dalam belajar, memiliki tanggung jawab, mampu mengatur perilaku dan kognisinya serta memiliki keyakinan diri.

Pada penelitian ini regulasi diri siswa kebanyakan dalam kategori sedang. Hal inilah yang menyebabkan siswa tidak mampu maksimal mengikuti proses pembelajaran. Siswa tidak bisa mengatur waktu dengan baik untuk menyelesaikan tugas-tugasnya, siswa juga tidak memiliki target yang ingin dicapai, sehingga apapun hasil yang diperoleh evaluasi diri untuk perbaikan tidak dapat dilakukan.

Beberapa hasil penelitian yang menunjukkan adanya hubungan signifikan antara persepsi siswa dengan hasil belajar melalui regulasi diri dijabarkan sebagai berikut. Hasil penelitian dari Sari dan Esti (2015) mendapatkan kesimpulan bahwa ada hubungan yang positif dan signifikan antara persepsi siswa terhadap mata pelajaran matematika, minat belajar siswa, dan kemandirian belajar siswa dengan hasil belajar matematika siswa kelas $\mathrm{X}$.

\section{Pengaruh Tidak Langsung Ekspektasi Karir terhadap Hasil Belajar Biologi Melalui Regulasi Diri}

Dari hasil analisis data yang diperoleh menunjukkan adanya pengaruh tidak langsung ekspektasi karir terhadap hasil belajar melalui regulasi diri. Ekspektasi karir memiliki pengaruh langsung yang signifikan terhadap hasil belajar dan regulasi diri sesuai dengan pembahasan pada hipotesis sebelumnya. Namun ekspektasi karir ternyata juga memiliki pengaruh tidak langsung terhadap hasil belajar melalui regulasi diri. Hal ini menunjukkan ekspektasi karir berkontribusi terhadap regulasi diri dan 
regulasi diri berkontribusi terhadap hasil belajar. Sesuai dengan pembahasan sebelumnya bahwa siswa dengan ekspetasi karir yang rendah cenderung memiliki hasil belajar yang rendah, terlebih lagi siswa tersebut memiliki regulasi diri yang rendah. Sebagian besar siswa memiliki ekspektasi karir yang sedang dengan hasil belajar sedang. Ekspektasi karir pada mata pelajaran biologi berpengaruh terhadap regulasi diri sehingga siswa yang memiliki ekspektasi yang sedang mendapatkan hasil belajar sedang karena siswa memiliki regulasi diri yang sedang pula.

Salah satu hasil penelitian yang menunjukkan hubungan antara regulasi diri dengan hasil belajar dilakukan oleh Ismayanti dan Nicholas (2014) yang menyatakan bahwa melalui regulasi diri seseorang dengan mudah akan menemukan gambaran masa depannya sehingga sangat penting untuk dapat mengembangkan keterampilan dalam melakukan regulasi diri pada setiap tugas yang melibatkan pemahaman diri serta kaitannya dengan keadaan di luar diri. Regulasi diri terdapat dalam setiap individu akan tetapi tidak semua individu dapat memanfaatkan hal tersebut pada situasi yang tepat, oleh karena itu regulasi diri perlu dilatih sehingga dapat menentukan pilihan - pilihan dalam hidup.

Ada beberapa faktor yang mempengaruhi keberhasilan seorang siswa untuk mencapai prestasi yang optimal. Di antaranya adalah intelegensi, kepribadian, lingkungan sekolah, dan lingkungan rumah. Namun selain faktorfaktor tersebut ternyata regulasi diri turut mempengaruhi keberhasilan siswa dalam mencapai prestasi yang optimal. Meskipun seorang siswa memiliki tingkat intelegensi yang baik, kepribadian, lingkungan rumah, dan lingkungan sekolah yang mendukungnya, namun tanpa ditunjang oleh kemampuan regulasi diri maka siswa tersebut tetap tidak akan mampu mencapai prestasi yang optimal (Susanto, 2006).

Pada penelitian yang dilakukan oleh Irmayanti (2013) ekspektasi karir berkontribusi positif dan signifikan terhadap prestasi belajar siswa sebesar
12,8\%. Dijelaskan lebih lanjut bahwa ekspektasi karir merupakan faktor internal yang berpengaruh terhadap prestasi belajar. Ekspektasi karir yang diharapkan siswa turut memberikan kontribusi terhadap prestasi siswa. Ekspektasi karir akan memberi dorongan yang kuat bagi siswa itu untuk lebih rajin belajar, sebab dengan mengetahui keadaan suatu karir akan timbul keinginan untuk memperoleh karir tersebut. Keinginan inilah yang menjadi motor penggerak untuk lebih rajin belajar. Dari paparan yang disampaikan dalam penelitian oleh Irmayanti ini juga dapat diketahui bahwa ekspektasi karir yang tinggi akan menjadi motor penggerak untuk dapat mengejar karir di mana keinginan atau motivasi ini akan berpengaruh terhadap regulasi diri. Dapat juga disimpulkan bahwa siswa yang memiliki ekspektasi karir yang rendah akan memiliki dorongan belajar yang lemah pula.

Rozali (2014) mengungkapkan bagaimana hubungan antara motivasi dan perilaku menentukan tujuan, seorang siswa mengetahui apa yang menjadi kebutuhan dan menetapkan tujuan akademiknya. Perilaku menentukan rencana, siswa memiliki tujuan ke depan dan membuat langkah-langkah untuk mencapai tujuan tersebut. Setelah menentukan rencana dan tujuan akademiknya, siswa tersebut fokus untuk menyelesaikan hal-hal yang dianggap sulit selama proses mencapai tujuan berlangsung atau yang disebut dengan mengontrol perhatiannya. Selanjutnya adalah memotivasi diri, yaitu keyakinan terhadap kemampuannya dalam mencapai tujuan yang diinginkan, yang kemudian memilih dari berbagai macam strategi belajar tergantung dengan kebutuhan dan tujuan belajar yang diinginkan. Hal selanjutnya adalah memonitor kemajuan dalam pencapaian tujuan dan mengubah strategi belajar atau memodifikasi tujuannya apabila dibutuhkan secara terus menerus (monitor diri sendiri). Siswa juga akan meminta bantuan orang lain, dengan bertanya kepada orang lain tentang halhal yang tidak mampu dikerjakan sendiri. Agar dapat mencapai tujuan yang diinginkan siswa melakukan evaluasi diri 
dengan memeriksa kembali hasil dari proses belajar yang telah dilakukan.

\section{PENUTUP}

Ada pengaruh signifikan antara persepsi siswa pada mata pelajaran biologi dan ekspektasi karir terhadap regulasi diri. Siswa yang memiliki persepsi positif dan ekspektasi karir tinggi di bidang biologi cenderung menyukai mata pelajaran biologi yang akan mengikuti proses belajar dengan baik. Dalam upaya mengikuti proses pembelajaran yang baik siswa akan memantau perilaku dirinya sendiri dan memodifikasi perilaku yang tidak sesuai untuk mencapai tujuan belajarnya.

Ada pengaruh yang signifikan antara persepsi siswa pada mata pelajaran biologi baik secara langsung maupun tidak langsung melalui regulasi diri terhadap hasil belajar. Persepsi siswa berpengaruh secara positif terhadap hasil belajar siswa. Hal terpenting yang mempengaruhi persepsi ini adalah konten dari mata pelajaran dapat diterapkan ke situasi kehidupan nyata akan mendorong sikap siswa yang lebih positif, siswa menyukai suatu mata pelajaran yang dianggap dekat dan berguna bagi kehidupannya sehariharinya.

Ada pengaruh yang signifikan antara ekspektasi karir baik secara langsung maupun tidak langsung melalui regulasi diri terhadap hasil belajar. Siswa dengan ekspektasi karir tinggi akan memiliki dorongan untuk mengikuti proses pembelajaran dengan baik dan akan terlihat pada hasil belajar yang baik. Karena hasil belajar diperoleh dari suatu proses interaksi tindak belajar yang dilakukan siswa. Melalui regulasi diri seseorang dengan mudah akan menemukan gambaran masa depannya sehingga sangat penting untuk dapat mengembangkan keterampilan dalam melakukan regulasi diri pada setiap tugas..
Saat proses pembelajaran, guru sebagai pendidik harus memahami bagaimana persepsi siswa terhadap mata pelajaran biologi serta hubungannya dengan hasil belajar. Bangun persepsi positif siswa pada mata pelajaran biologi dengan memberikan contoh nyata bahwa biologi dekat dan bermanfaat bagi kehidupan siswa serta dengan lebih sering melakukan kegiatan observasi dan praktikum agar siswa mengenal secara langsung objek-objek biologi. Pada setiap kompetensi dasar di kelas $X$ yang diajarkan guru sebaiknya membawa objek biologi yang sedang diajarkan, bukan hanya menampilkan lewat gambar dan video. Misalnya pada materi protista siswa melakukan pengamatan langsung air kolam, air got, dan air rendaman jerami di laboratorium. Saat mempelajari materi plantae, siswa membawa langsung contoh tanaman yang dimaksud dan melakukan pengamatan terhadap strukturnya. Di kelas XI siswa mempelajari tentang sistem-sistem pada tubuh manusia, dalam proses pembelajaran guru harus mengaitkan penyakit atau fenomena sehari-hari yang sering dijumpai siswa.

Oleh karena ekspektasi karir menyumbang kontribusi yang besar terhadap hasil belajar biologi maka informasi tentang pilihan karir sangat penting untuk diketahui siswa. Guru saat kegiatan pembelajaran sebaiknya memberikan pilihan-pilihan karir yang dapat dipilih oleh siswa nantinya, terutama pilihan karir terkait biologi yang biasanya tidak umum diketahui oleh siswa. Pengenalan karir ini dapat dilakukan sepanjang pelajaran terkait dengan materi yang sedang didiskusikan. Namun sebaiknya contoh-contoh karir dikenalkan kepada siswa di kelas $X$ saat siswa mempelajari materi ruang lingkup biologi sehingga keinginan siswa untuk memperoleh nilai baik pada mata pelajaran biologi dimulai sejak awal kelas $\mathrm{X}$. 


\section{DAFTAR RUJUKAN}

Anggraeni, Puspita. 2015. Hubungan Antara Persepsi terhadap Tugas Akademik dan Atraksi Interpersonal Siswa terhadap Guru dengan Regulasi Diri Siswa Program Olimpiade Sains Nasional (OSN) SMA Negeri 10 Samarinda. EJournal Psikologi Volume 3 Nomor 2. (hal. 504-516).

Fritz1, Barbara Smolej dan Cirila Peklaj. 2009. Self-regulated Processes as Predictors of Students' Achievement in Music Theory in Slovenian Elementary Music Schools. Horizons of Psychology. Volume 18 Nomor 4. (hal. 5-18).

Hussaini, lliyasu., Lee Ming Foong1., dan Yahya Kamar. 2015. Attitudes of Secondary School Students towards Biology as a School Subject in Birninkebbi Metropolis, Nigeria. International Journal of Research \& Review Volume 2 Nomor 10. (hal. 596-600).

Irmayanti, L.P.Susy.,I.M. Yudana2., dan A.A.I.N.Marhaeni. 2013. Kontribusi Persepsi Siswa tentang Kemampuan Guru Mengelola Pembelajaran, Kemampuan Verbal, dan Ekspektasi Karir terhadap Prestasi Belajar Bahasa Inggris Siswa Kelas XI IPA pada SMA Negeri Di Kecamatan Tabanan. e-Journal Program Pascasarjana Universitas Pendidikan Ganesha Volume 4.

Istriyanti, N.L.A. dan Nicholas, S. 2014. Hubungan Antara Regulasi Diri dan Perencanaan Karir pada Remaja Putri Bali. Journal Psikologi Udayana Volume 1 Nomor 2. (hal. 301-310).

Krisnawan, I Ketut Maha. 2013. Kontribusi Ekspektasi Karir, Motivasi Belajar Siswa dan Kualitas Sarana Laboratorium terhdapat Kualitas Pelaksanaan Pembelajaran Praktikum. Tesis (tidak diterbitkan). Program Pasca Sarjana Universitas Pendidikan Ganesha.
Manrihu, Mohammad Thayeb.1992. Pengantar Bimbingan dan Konseing Karier. Jakarta: Bumi Aksara.

Prokop, Pavol., Matej Prokop., dan Sue Dale Tunnicliffe. 2007. Is Biology Boring? Student Attitudes Toward Biology. JBE Volume 42 Nomor 1. (hal. 36-39).

Rozali, Y. A. 2014. Hubungan Self Regulation dengan Self Determination (Studi Pada Mahasiswa Aktif Semester Genap 2013/2014, Ipk $\leq 2.75$, Fakultas Psikologi, Universitas X, Jakarta). Jurnal Psikologi Volume 12 Nomor 2. (hal. 61-66).

Sadiyah, Rika. 2016. The Correlation of Attachment, Self Regulation, Autonomy to Social Intelligences. Makalah disajikan dalam The 2nd International Multidisciplinary Conference. Jakarta, 2016 November.

Sarwono, Sarlito Wirawan. 2010. TeoriTeori Psikologi Sosial. Jakarta: PT Raja Grafindo Persada.

Susanto, Handy. 2006. Mengembangkan Kemampuan Self Regulation untuk Meningkatkan Keberhasilan Akademik Siswa. Jurnal Pendidikan Penabur Volume 5 nomor 7. (hal. 64-71).

Timbowo, Elfira. 2014. Determinasi Komitmen Kerja Guru, Kualitas Pengolahan Pembelajaran, dan Ekspektasi Karir terhadap Prestasi Belajar Bahasa Jepang. Tesis (tidak diterbitkan). Program Pasca Sarjana Universitas Pendidikan Ganesha.

Zimmerman, Barry J. 2008. Investigating Self-Regulation and Motivation: Historical Background, Methodological Developments, and Future Prospects. American Educational Research Journal Volume 45 Nomor 1.(hal.166-183). 
Jurnal_ep, Vol. 8 No. 2, Agustus 2018 